\title{
THE ESSENCE OF INTEGRATED BUSINESS APPLICATION COURSE TO ENHANCE STUDENTS' ENTREPRENEURIAL SKILLS
}

\author{
Claudius Bona* \\ claudius@staff.ubaya.ac.id
}

\begin{abstract}
People talk about entrepreneurship simply everywhere. This trend also happens in Indonesia as it is proved with the increase of $3.1 \%$ entrepereneurship development ratio in 2016 (www.depkop.go.id). The hype is supported by the expansion of $e$-commerce in Indonesia. The rise of e-commerce entrepreneurs in Indonesia is one of the factors that makes Business English study program to set up Integrated Business Applications (IBA) course. The course is intended to make students learn to do business activities by doing real online business. This research would like to reveal whether the IBA course could enhance students' entrepreneurial skills or not. This research uses fifth semester students who already passed this course as respondents. The findings of this research reveal that Integrated Business Applications course is really essential to enhance students' entrepreneurial skills. Further research could be implemented in order to find the impact of this course to the other study program.
\end{abstract}

Keywords: Entrepreneurship, Entreprenurial skills, Integrated Business Applications, Business English study program.

\section{Introduction}

Entreperenurship is everywhere. People talk about entrepreneurship and the needs of becoming entrepreneurs simply everywhere, such as at the business offices to local markets, at international restaurants to small coffee shops in the corner of a street. This trend also happens in Indonesia as it is proved with the increase of 3.1\% entrepreneuship development ratio in 2016 (www. depkop.go.id). The State Minister for Coop- eratives Small and Medium Enterprises of Indonesia even targeted 4\% ratio increases in 2017. The hype to become a succesful entrepreneur is supported by the expansion of e-commerce in Indonesia. The existence of online shop is simply booming in Indonesia. Small and medium enterprises can directly go online and sell things without having to think about permanent physical stores. The Indonesian government even support the small and medium enterprise to have and

* Lecturer of Business English Study Program, Politeknik Ubaya, Surabaya. 
register their own websites. The practicality and effeciency of online business transaction make people buy online rather than go to the nearest physical stores. Even in October 30. 2017, CNN Indonesia published a shocking news report video stated that several depeartment stores in Indonesia had closed their physical stores. It seemed that retail stores in Indonesia were being hit hard by the online stores.

The rise of e-commerce entrepreneurs in Indonesia is one of the factors that makes Politeknik Ubaya, especially Business English study program to set up Integrated Business Applications course. The course is intended to make students learn to do business activities by starting and running real online business. They have to make several business deals with real customers by online as well as by offline transacation. The students also have to complete the module that is given by the study program. In all activities, they have to work in a team with clear organization structure as well as members' job descriptions. The team members also consist of other study program students in order to strengthen the relationship between Business English students with other study program students. Therefore, the students basically practice the real entrepreneurship activities in this Integrated Business Applications (IBA) course.

This research would like to discover whether the Integrated Business Applications course could enhance students' entrepreneurial skills or not. Previous researches on similar issues are investigated thoroughly to reveal the essence of Integrated Business Applications to enhance entrepreneurial skills. This research uses fifth semester students of Business English study program of Politeknik Ubaya as the respondents, since they already passed Integrated Business Applications course.
The findings of this research could be used to reveal whether Integrated Business Applications course is really essential to enhance students entrepreneurial skills. This research could be beneficial for Politeknik Ubaya as a feedback whether this course really runs effective as well as beneficial to increase students' skills, especially entreprenerial skills. Further study could be implemented in order to find the impact of this course to the other study program.

\section{Research Methods}

This research would explore the essence of Integrated Business Applications course to enhance students' entrepreneurial skills. The writer focuses on the semester five students of Business English study program Politeknik Ubaya as the respondents since they all passed this course. The result of this research could not be generalized with the other students. This study uses quantitative descriptive method and therefore the writer would use questionnaires for this research as a tool to reveal whether Integrated Business Applications course could enhance students' entrepreneurial skills or not. It is distributed to 14 active semester five students of Business English study program of Politeknik Ubaya, The questionnaires are divided into three sections; section one is about Integrated Business Applications actvities, while section two is about Entrepreneurial skills in IBA course, and finally, section three is about the impacts of IBA course to enhance students' entrepreneurial skills. On section two and section three, the writer gives several questions that are related with technical, business management, and personal entrepreneurial skills. Moreover, the writer always gives open ended questions in every section in order to cross check the students statements. There are 48 total closed ended and three open ended questions in the questionnaires. 


\section{Literature Review}

\section{The Definition}

Integrated Business Application (IBA) course is the multi subject-integrated course that is given to semester four students in order to prepare students for the real working world by providing real e-commerce (online business) activities.

Entrepenurship is the process by which individuals pursue opportunities without regarding to resources they currenly control (Barringer and Ireland, 2016).

\section{Entrepreneurship Skills}

The Organisation for Economic Co-operation and Development (OECD) has identified three main groups of skills required by entrepreneurs.

1. Technical - specific operation technology, communication, interpersonal relations, organizational ability, coordinating team members, environmental observation;

2. Business management - planning, formulating goals, decision making, motivating, marketing, accounting, negotiation;

3. Personal entrepreneurial - inter discipline, risk-seeking, innovation, changeorientation, persistency, visonary.

Engendering entrepreneurship skills involve developing:

1. Specific, technical business-running skills e.g. developing and implementing a business plan, accounting, budgeting;

2. Transversal or strategic skills associated with entrepreneurship: an ability to take decisions based on balanced risk assessment and information analysis; recognising and implementing opportunities for business growth; following market developments and managing the products and services offer.

The European Commission recognises entrepreneurship as a key competence for life and the 'Rethinking Education' commu- nication and also states that all young people should gain benefits from entrepreneurship education, including 'at least one practical entrepreneurial experience before leaving compulsory education'. Entrepreneurship is a key element of the Europe 2020 strategy. A number of countries have developed entrepreneurship education strategies and there is an emerging body of knowledge about good and effective practice in learning and teaching. Ministries, institutions and inspirational teachers are working to integrate learning and the acquisition of transversal entrepreneurship skills, knowledge and behaviours; not just into 'entrepreneurship' courses but across the curriculum, into the classroom and across schools, colleges and universities.

The writer will use the three main groups of skills set up by OECD as a basis for his research to investigate whether Integrated Business Applications course is really essential to enhance students' entrepreneurial skills or not. He will elaborate all aspects of skills which are technical, business management, and personal entrepreneurial skills.

\section{Entrepreneurship Education}

The definition about entrepreneurship education have been discussed in several papers. Erkkilä (2000) has proposed entrepreneurship education as encompassing both enterprise and entrepreneurship education. According to Lackeus (2005), in Northern and Eastern Europe some additional terms are used. In Sweden and the Balkans the term entrepreneurial learning is often used as an equivalent to enterprise education. Another set of terms used in Finland is internal entrepreneurship education and external entrepreneurship education. Internal entrepreneurship education is a synonym to enterprise education, and external entrepreneurship education is a synonym to entrepreneurship education. Adding to the confusion, here is the fact that internal entrepreneurship is sometimes used as a synonym to intrapre- 
neurship, i.e. when acting entrepreneurially in an established organization.

According to Mwasalwiba (2010), teaching "about" entrepreneurship means a combination of content and theoretical approach aiming to give a general understanding of the phenomenon. It is the most common approach in higher education institutions. Teaching "for" entrepreneurship means an occupationally oriented approach aiming at giving budding entrepreneurs the requisite knowledge and skills. While Kyrö (2005) stated that. teaching "through" means a process based and often experiential approach where students go through an actual entrepreneurial learning process.

Jack and Anderson (1999) from University of Abergen conducted a research related with the needs of entrepreneurship education in enterprise culture. They already practice teaching entrepreneurship course. They also realise the limitations of their own experience so they attempt to bridge this gap between theory and entrepreneurial practice using a number of techniques. Some of the techniques are using external resources' experiences, in this case, by inviting some entrepreneurs;. They also advise students on research in small business and encourage students to engage with small business and entrepreneurs at every opportunity. They ask their students to talk and listen to practise entrepreneurs whenever they can. At the same time they attempt to build theory into every learning activity as a critical framework, aiming to develop the students' understanding of entrepreneurship. One important aspect of this is the students' final dissertations where they expect students to use theory to critically review current entrepreneurial practice.

Jack and Anderson clarify that as academics they should recognise that entrepreneurship is both an art and a science so that their contribution should build critical theoretical knowledge about entrepreneur- ship and endow students with the management skills necessary for an entrepreneurial career. According to them, raising awareness of entrepreneurship is relatively straight forward and can be achieved through teaching examples, case studies and by bringing entrepreneurs into the class. Similarly teaching entrepreneurial theories and good management skills conforms to academic norms. Consequently the outcome of entrepreneurship education should be the creation of reflective practitioners fit for an entrepreneurial career.

Based on several researches above, the writer can conclude that entrepereneurship education deals with both enterprise and entrepreneurship education. Moreover, teaching entrepreneurship requires both knowledge or theory, skills, as well as experience. For enhancing the experience, lecturers could invite entrepreneurs as practioners in order to share real life business experience to the students. It seems Integrated Business Applications course that is designed by study program and Politeknik Ubaya has already on the right track to teach entrepereneurship.

\section{Findings}

The findings will reveal the data related with Integrated Business Applications (IBA) course students' activities, entreprenerial skills that students get from IBA, and impact of IBA course to enhance students' entrepreneurial skills.

\section{Integrated Business Applications (IBA) Activities}

The result of the questionnaire showed that all 14 semester five students of Business English study program had already passed Entrepreneurship class as well as Integrated Business Applications course. It meant that all students were qualified to become the respondents of the research. There were $21 \%$ students that conducted this course inside and outside the classroom everyday, while 
43\% students managed this course three until five days in a week, and the rest 36\% students only involved in one or two days only. The result showed that the total $64 \%$ students immersively and pro actively involved in this course even out of their classroom time. Concerning with the self study freedom in IBA, 79\% students agreed that they enjoyed their self-study time, and the other $7 \%$ students strongly agreed with this as well. On the other hand, the total $14 \%$ students disagreed and strongly disagreed that they enjoyed the situation. It seemed almost all students ( $86 \%$ respondents) really enjoyed the self-study situation in this course. Related with the module assignment, 50\% students always did the assignment and the other $14 \%$ students almost always did the task. On the contrary, $36 \%$ students state that they only sometimes did this. It meant $86 \%$ students diligently did their assigments.

Concerning with e-commerce activities and transactions, $36 \%$ students always used their e-commerce online application in this course and $50 \%$ students almost always used it, while the $14 \%$ of them used it sometimes. It seemed all students already tried to use online application and $86 \%$ of them used it frequently. $21 \%$ students always did online transactions with their customers in this IBA course and $36 \%$ of them almost always did it. While $43 \%$ students did it sometimes. It revealed that all students conducted online transactions in this course with the total 57\% of them did it frequently. Moreover, 29\% students almost always did the offline transaction with the customers and 57\% students did it sometimes while the rest $14 \%$ of them never used offline transactions. All students had already experienced a closing deal situation. It meant their products had already sold with the condition $29 \%$ of them always and $36 \%$ of them almost always sold as well as $36 \%$ of them sometimes sold. The percentage showed that students preferred to do online to offline transactions in this course. It revealed that $29 \%$ students always and $36 \%$ of them almost always preferred to conduct online transactions. While 29\% students preferred the online transactions sometimes and only $7 \%$ students preferred to conduct offine to online transactions. $14 \%$ students strongly agreed and $71 \%$ of them agreed that previous entrepreneurial skills helped them to overcome the IBA course, while the rest $14 \%$ students disagreed with this statements. Furthermore, 21\% students strongly agreed and $79 \%$ agreed that this IBA course could enhance their entrepreneurial skills. It revealed that all students believe their previous entrepreneurial skills helped them in this course while the IBA course itself could help them enhance their entrepreneurial skills. In another word, Integrated Business Application course was essential to enhance students' entrepreneurial skills.

All students had filled their open ended questions in the questionnaire. It revealed that students believed this subject was important to enhance their entrepreneurship knowledge and skills in this digital era by conducting real e-commerce.. Students also believed this was a great program for business students to implement the theories from class. They also learned how to do accounting and negotiation through online with the real customers. It seems that the result of the open ended questions was closely related with the closed ended one.

\section{Entrepreneurial Skills on Integrated Business Applications Course}

The writer divided this section into three categories which are technical, business management, and personal entrepreneurial skills. On technical skills aspect, all students stated that they used and acquired specific technolgy. They all also communicated well with the customers $21 \%$ students stated they strongly agree and $79 \%$ of them agree they already communicate with the customers and friends. Concerning with interpersonal relationship skill, 14\% students strongly agreed that they had built strong relationships and 
the other $79 \%$ agreed with this statement as well. $14 \%$ of them also strongly agreed and $79 \%$ of them agreed that they performed strong organizational ability in the team. Furthermore, 14\% students strongly agreed that they coordinated with their team members and the other $71 \%$ of them also agreed with this statement. On the other hand, 14\% students disagreed that they coordinated with team members. $7 \%$ students strongly agreed and $64 \%$ of them agreed that they observed the working environment. The rest $29 \%$ of them disagreed that they observed their working environment. It revealed that the students performed good technical entrepreneurial skills in Integrated Business Applications. It was proved by almost all or more than $80 \%$ students performing their technical skills, such as acquired specific technology, communication and interpersonal skills, organizational ability, coordination and observation skills.

On business management skills aspect, the total $78 \%$ students strongly agreed that they planned in this course. Moreover, 71\% students strongly agreed that they formulated goals. $14 \%$ strongly agreed and $71 \%$ agreed that they practised decision making in this course. $21 \%$ students strongly agreed that they motivated themselves and others in the group. $71 \%$ students also agreed with this statement and made total $92 \%$ students acquire motivation skill. Furthermore, 29\% of them strongly agreed and $64 \%$ of them agreed that they sucessfully marketed their products in this course. While the total 71\% students strongly agreed they did the accounting in IBA course. Finally, 14\% students strongly agreed and 79\% of them agreed they already conducted good business negotiations. It revealed that the students also acquired good business management skills based on their statements. The data showed almost all students had planned and formu- lated goals skills, decision making and motivating skills, as well as marketing, accounting, and negotiation skills.

Concerning personal entrepereneurial skills aspect, $36 \%$ students strongly agreed that they performed self-discipline as well as the other $43 \%$ students who also agreed with this statement. $36 \%$ of them strongly agreed and $57 \%$ of them agreed that they seeked 'risk' in the transactions. Moreover, all of the students tried to innovate in IBA course and $85 \%$ of them were willing to change orientation if there was new hope. $78 \%$ of the students also strongly agreed that they persisted in seeking goals. Finally, the students who are also visonary ( $85 \%$ of them ) strongly agreed this statement. The data also showed that students had acquired personal entrepreneurial skills since most of them had self-discipline and risk-seeking skills, innovation and change-orientation, as well as persistence and visonary.

The students stated in the open ended questions that they learned entrepereneurial skills by conducting real e-commerce situation through this course. They also believed that the role of team member was important in this subject. Students also believed this course was formulated with completed managemnet skills that would be the foundation for them. The students believed that through this course they could be visionary and think differently. These statements were correlated with their statements in the closed ended questions that they believed IBA course could enhance their entrepreneurial skills.

\section{Impact of IBA Course to Enhance Stu- dents' Entrepreneurial Skills}

Ths section covered the impact of IBA course to the entrepreneurial skills development. It also divided into three categories, which were the impacts on technical, business management, and personal entrepreneurial skills. On technical skills aspect, all students stated that they IBA course could 
enhance their skills in using and acquiring specific technolgy, in particular e-commerce apps. 78\% students also strongly agreed that this course could enhance their communication skill while the total $85 \%$ students believed that their interpersonal skill had improved after they followed this course. Furthermore, 14\% strongly agreed and $79 \%$ of them agreed that their organizational ability, organizational, and coordination skill also had improved because of the IBA course. All students also believed that their observation skill had improved after they followed this course. It seemed that Integrated Business Applications course could enhance students' entreprenurial in technical skills which covered specific technology, communication and interpresonal relations skills, organizational ability, coordination and observation skills.

Concerning with business management aspect, $14 \%$ students strongly agreed and $71 \%$ of them agreed that IBA course could enhance their planning and goal formulating skills. All of the students also believed that their decision making skill had improved after completing this course. Moreover, $14 \%$ students strongly agreed and $71 \%$ of them agreed that their motivating skill had improved. Total $85 \%$ of them also strongly agreed their marketing skill also improved as well as total $64 \%$ students who thought their accounting skill also improved. Finally, $92 \%$ students believed that their business negotiations skill had improved after joining IBA course. It seemed that Integrated Business Applications course could enhance students' entreprenurial in business management skills which covered planning and formulating goals skills, decision making and motivating skills, as well as marketing, accounting, and negotiation skills. It was because they had already joined and completed Integrated Business Applications course.

On personal entrepereneurial skills aspect, 36\% students strongly agreed and
$43 \%$ students agreed that their self-discipline skills had improved after completing the IBA course. Total $85 \%$ students believed that risk-seeking skill had improved as well. Moreover, 29\% students strongly agreed and $57 \%$ of them agreed that IBA could enhance their innovation skill. Total 93\% students strongly agreed and agreed that IBA also could enhance their willingness to change orientation if there was new hope. $29 \%$ students strongly agreed and $50 \%$ of them agreed that IBA could enhance their persistence skill as well as their visionary skill. It revealed that Integrated Business Applications course could enhance students' personal entrepreneurial skills which covered self-discipline and risk-seeking skills, innovation and change-orientation, as well as persistence and visonary. It is supported by the fact that most of the students believed this course was beneficial to enhance their entreprereneurial skills.

Students stated in the open ended questions that they got a lot of entrepreneurial knowledge and skills especially in e-commerce from IBA course. They urged this course still to be continued since this was the only course that they could deal with the real customers. Students believed that they could be more innovative, better in identify problems, and self-discipline. Finally, they believed this course could enhance their entrepreneurial skills and it was correlated with their response in closed ended questions.

\section{Conclusions and Suggestions}

This research reveals that Integrated Business Applications course could enhance all of Business English students' entrepreneurial skills. These skills are technical, business management, and personal entrepreneurial skills. The technical skills cover specific technology, communication and interpresonal relations skills, organizational ability, coordination and observation skills. While business management skills cover planning 
and formulating goals skills, decision making and motivating skills, as well as marketing, accounting, and negotiation skills. Finally, there would be personal entrepreneurial skills that deal with self-discipline and riskseeking skills, innovation and change-orientation, as well as persistence and visonary. However, the results of this research could be elaborated more in the further research by adding some contributing factors, such as analyzing the role of the team work as well as challenges the students face in doing the e-commerce. Further research also can be implemented to find the impacts of this course to the other study program students. It is suggested that Politeknik Ubaya, especially Business English study program continue to develop the existance of Integrated Business Applications course, since this course would give significant impacts by enhancing students' entrepreneurial skills. By doing this, the study program conducts good entrepreneurship education by providing knowledge, skills, and real business experience to the students.

\section{References}

Briga Hynes. 1996. Entrepreneurship Education and Training - Introducing Entrepreneurship into Non Business Disciplines. Journal of European Industrial Training, Vol. 20 Issue: 8, pp.10-17.

Cotterill, Keith. 2012. A Comparative Study of Entrepreneurs'Attitudes to Failure in Technology Ventures. Journal of Innovation Science, Vol. 4 Issue: 2, pp.101-116.

Culkin, Nigel. 2016. Entrepreneurial Universities in the Region: the Force Awakens? International Journal of Entrepreneurial Behavior \& Research, Vol. 22 Issue: 1, pp.416

Dickson, Pat H, George T. Solomon,and K. Mark Weaver. 2008. Entrepreneurial Selection and Success: Does Education Matter? Journal of Small Business and Enterprise Development, Vol. 15 Issue: 2, pp.239-258

Erkkilä, K. 2000. Entrepreneurial Education: Mapping the Debates in the United States, the United Kingdom and Finland, Abingdon, Taylor \& Francis.

Galanakis, Kostas, and Paraskevi Giourka. 2017. Entrepreneurial Path: Decoupling the Complexity of Entrepreneurial Process. International Journal of Entrepreneurial Behavior \& Research, Vol. 23 Issue: 2, pp.317-335.

Garalis, Algirdas, and Gražina Strazdienè. 2007. Entrepreneurial Skills Development via Simulation Business Enterprise. Social Research / Socialiniai tyrimai. 2007. Nr. 2 (10), 39-48

Gibb, Allan. 2007. Enterprise in Education Educating Tommorrows Entrepreneurs. Pentti Mankinen 2007

Jabeen, Fauzia, Mohd. Nishat Faisal, and Marios I. Katsioloudes. 2017. Entrepreneurial Mindset and the Role of Universities as Strategic Drivers of Entrepreneurship Evidence from the United Arab Emirates. Journal of Small Business and Enterprise Development, Vol. 24 Issue: 1, pp.136-157.

Jack, Sarah L, and Alistair R. Anderson. 1999. Entrepreneurship Education Within the Enterprise Culture Producing Reflective Practitioners. International Journal of Entrepreneurial Behavior \& Research, Vol. 5 Issue: 3, pp.110-125 
Julianto, Pramdia Arhando. 2017. 2017, Menkop Targetkan Rasio Kewirausahaan Meningkat. retrieved from http://ekonomi.kompas.com/read/2017/03/21/220000826/2017. menkop.targetkan.rasio.kewirausahaan.meningkat

Kyrö, P. 2005. Entrepreneurial learning in a cross-cultural context challenges previous learning paradigms. In: Kyrö, P. \& Carrier, C. (eds.) The Dynamics of Learning Entrepreneurship in a Cross-Cultural University Context. Hämeenlinna: University of Tampere.

Lackeus, Martin. 2015. Enterprise in Education: What, Why, When, How. Entrepreneurship 360, Background Paper. OECD.

Marques, Carla S., Joao J. Ferreira, Daniela N. Gomes, and Ricardo Gouveia Rodrigues. 2012. Entrepreneurship Education How Psychological, Demographic and Behavioural Factors Predict the Entrepreneurial Intention. Journal Education + Training, Vol. 54 Issue: 8/9, pp.657-672.

Mohamad, Noorkartina, Hock-Eam Lim, Norhafezah Yusof, and Jan-Jan Soon. 2015. Estimating the Effect of Entrepreneur Education on Graduates' Intention to be Entrepreneurs. Journal Education + Training,Vol. 57 Issue: 8/9, pp.874-890.

Mwasalwiba, E. S. 2010. Entrepreneurship Education: a Review of its Objectives, Teaching Methods, and Impact Indicators. Journal Education + Training, 52 20-47.

Palalić, Ramo, Veland Ramadani, Arnela Đilović, Alina Dizdarević, Vanessa Ratten. 2017. Entrepreneurial Intentions of University Students: A Case-based Study. Journal of Enterprising Communities: People and Places in the Global Economy, Vol. 11 Issue: 03, pp.393-413.

Rasio Wirausaha Indonesia Naik Jadi 3.1 Persen. retrieved from http://www.depkop.go.id/ content/read/ratio-wirausaha-indonesia-naik-jadi-31persen

Soetanto, Danny. 2017. Networks and Entrepreneurial Learning: Coping with Difficulties. Journal of Entrepreneurial Behavior \& Research, Vol. 23 Issue: 3, pp.547-565.

Tawil, N. M. R. Hassan, S. Ramlee, and Z. K-Batcha. 2015. Enhancing Entrepreneurship Skill Among University's Students By Online Business Simulation. Journal of Engineering Science and Technology Special Issue on 4th International Technical Conference 2014, June (2015) 71-80 
